\title{
Navigating the job search after incarceration: the experiences of work-release participants
}

\author{
Andrea Cantora* \\ School of Criminal Justice, College of Public Affairs, University of Baltimore, 10 West \\ Preston Street, Suite 516, Baltimore, MD 21201, USA
}

(Received 21 March 2014; accepted 17 July 2014)

\begin{abstract}
When prisoners return to the community they often strive to obtain immediate employment. However, finding work after being released from prison is one of the major challenges returning prisoners face. With few employment prospects due to legal restrictions, discrimination from prospective employers, and multiple individual and community barriers offenders often end up accepting lowskilled work with little opportunity for growth. This qualitative study examines the job searching process for women residing in a community correction workrelease facility. The researcher identified several barriers to securing employment, as well as many factors that facilitated the process. Sources of help, types of jobs secured, and experiences with stigma and discrimination are discussed. Implications for improving the job searching process for this population are discussed.
\end{abstract}

Keywords: employment; community corrections; work-release; women offenders; re-entry

\section{Introduction}

Each year approximately 600,000 prisoners return to the community (Carson \& Golinelli, 2013). Upon release from prison concerns about housing, employment, family reunification, and treatment needs are core issues that require immediate action. When prisoners return to the community they often strive to obtain immediate employment. Work serves as an informal social control mechanism to prevent criminal behavior (Sampson \& Laub, 1993; Visher, Debus-Sherrill, \& Yahner, 2011). However, finding work after being released from prison is one of the major barriers to successful re-entry (Travis, 2005; Visher et al., 2011). There is a wealth of literature on the multiple barriers returning prisoners experience when searching for employment. These include state laws preventing employers from hiring (Legal Action Center, 2004), the availability of low-skilled jobs, the correctional systems' low capacity to enhance prisoner vocational skills (Lynch \& Sabol, 2001), and individual factors such as low educational attainment, unemployment history, and lack of work experience (Western, 2007). Other challenges associated with securing employment include health issues, mental health problems, and having a history of substance abuse (Visher, Debus-Sherrill, \& Yahner, 2008). Most of the barriers identified are experienced by prisoners released straight to the community after

*Email: acantora@ubalt.edu 
incarceration, or on parole supervision. There is little research examining employment barriers from prisoners released to a work-release halfway house. This study examines women's experiences obtaining employment while residing at a workrelease community correction facility.

\section{Employment barriers}

There are many challenges related to finding work after incarceration. To start, educational attainment levels contribute to the complexities associated with securing and maintaining employment. For example, $37 \%$ of state and federal inmates do not have a high school diploma or GED; and 78\% lack postsecondary education (Greenberg, Dunleavy, \& Kutner, 2007). These statistics are troubling considering educational attainment is linked with employability and earnings. According to the US Census Bureau, individuals with an associate or bachelor's degree earn more than those with a high school diploma or less (Bureau of Labor Statistics, 2003). Research finds that higher educational levels and higher earnings are correlated with lower levels of recidivism (Chappell, 2004; Visher et al., 2008). Higher education, however, is not the only indicator of employment success. Research conducted on a sample of Texas women offenders found that women with a high school diploma or GED, prior work experience, and engagement in prison job training are more likely to obtain and maintain employment within the first year of release from prison compared to women without these characteristics (La Vigne, Brooks, \& Shollenberger, 2009).

In addition to limited education, many returning prisoners have poor employment histories and lack work skills necessary for securing work. Visher et al. (2011) studied former prisoners' employment experiences by examining individual factors that impact their ability to find work. They found that individuals with little to no-employment history had poorer work outcomes than individuals with a history of recent and consistent employment. There is a long-standing theory that legitimate employment enhances social ties to conventional norms, therefore decreasing crime (Sampson \& Laub, 1993). Empirical research finds support for this theory - having stable employment decreases recidivism (Visher \& Travis, 2003). Specifically, research finds that returning prisoners who work more hours and earn higher incomes have lower levels of recidivism (Visher et al., 2008). Furthermore, the quality of work also plays a role in future crime and social control, whereas higher quality jobs decrease criminal motivation and increase social control (Uggen, 1999).

Health factors also serve as a barrier to employment. For example, Visher et al. (2011) found that drug relapse immediately after release, and the presence of chronic physical and mental health conditions impacted length of employment prior release. Women, specifically, struggle due to the lack of treatment options for substance abuse, physical and mental health problems, and unresolved trauma issues (Richie, 2001). Other life factors play a role as well. Obligations to pay debt also played a role in maintaining work, as did being married and having close relationships with children (Visher et al., 2011). Furthermore, women face additional work challenges because they are often the primary caregiver for young children, and access to affordable childcare is not always available (Berman, 2005; Flowers, 2010; Richie, 2001). For women, re-establishing relationships with family and children is critical to successful re-entry (O'Brien, 2001; Richie, 2001). 
With few employment prospects and little money to support themselves returning prisoners rely heavily on social networks. Family and friends often end up financially supporting returning family members (Mallik-Kane \& Visher, 2008). Though some research indicates that learning about job opportunities through social networks is often weakened as a result of incarceration (Western, Kling, \& Weiman, 2001), many returning prisoners often secure job opportunities through friends, family, and former employers (Nelson, Perry, \& Allen, 1999; Solomon, Roman, \& Waul, 2001). Visher et al. (2011) found that one of the most successful job searching strategies for participants was returning to a previous job. Participants in Visher et al.'s study also believed that employers were reluctant to hiring them due to their criminal record. Maintaining a job after securing one was another challenge for participants. Sixty-five percent of Visher et al.'s sample found a job after release, but less than half maintained their job. Relying on family and friends for financial support was a common occurrence for almost half of the sample eight months after release.

Economic conditions within communities also impact the employment prospects for returning prisoners. Considering most returning prisoners are released to urban areas, access to jobs may be a barrier. Both the loss of labor markets in urban areas, and the competition with other low-skilled residents, impacts employment options (Lynch \& Sabol, 2001). While most research on labor markets and the exoffender population has focused mostly on men, Lalonde and Cho's (2008) research on women offenders indicated that spending time in prison may actually enhance employment prospects for women rather than harm them. Their research indicates that prison time is associated with increased employment rates. Specifically, they suggest that their findings indicate women are more likely to enter the workforce after leaving prison. Although they don't elaborate on why this may be the case, it is possible that parole work requirements force women to enter the labor market.

Another major barrier of securing employment is the public perception of criminal records and the discrimination that results. When searching for work, returning prisoners must also deal with the stigma associated with having a criminal record (Sampson \& Laub, 1993; Solomon et al., 2001; Western et al., 2001). Employers may view people with criminal records as untrustworthy, a threat to their business, and a potential legal liability (Holzer, Raphael, \& Stoll, 2004). This stigma is known to decrease employer's willingness to hire returning prisoners, resulting in difficulties finding jobs (Pager, 2002; Petersillia, 2001). For example, Holzer et al.'s (2004) study examining employers' reluctance on hiring a person with a criminal record indicated that a majority were unwilling to hire. For women in particular, the social and economic marginalization they have historically faced adds to the barriers of finding equal work and pay after spending time in prison (Scroggins \& Malley, 2010). Additionally, women returning from prison face even greater stigma than their male counterparts due to their higher rates of substance abuse, mental health issues, and health-related problems (LeBel, 2012). Furthermore, LeBel found that women perceive more reasons for discrimination than men, including criminal record, gender, sexual orientation, and mental health disorders.

To alleviate some of the barriers returning prisoners experience, many states utilize community corrections programs to address employment needs. Halfway house facilities are one type of community intervention that provide returning prisoners an opportunity to secure employment, save money, and have a place to 'get back on their feet' (Latessa, 2004, p. 138). Halfway houses, also called community 
correction facilities, were originally developed due to the ineffectiveness of traditional prison programs, to reduce overcrowding, and as a cost-effective strategy to keep prisoners in the community (Donnelly \& Forschner, 1987; Latessa \& Allen, 1982). Described by Latessa and Travis (1991):

Halfway houses provide the security of a structured controlled residence, similar to incarceration, combined with the freedom of residents to seek and engage in employment and other activities in the free community. (p. 54)

Researchers who have evaluated halfway house programs reported that women who transitioned through these programs have lower recidivism rates than those who have not (Mackey \& Fretz, 2007; O'Brien, 2002). Other re-entry programs that share common characteristics with the services provided by halfway house facilities have also been successful at reducing recidivism. For example, transitional job programs that place returning prisoners into temporary employment while also providing support services have been successful at reducing recidivism (Redcross, Bloom, Azurdia, Zweig, \& Pindus, 2009). Additionally, holistic case management programs that provide comprehensive services for up to two years post release improve offenders' employment outcomes and reduce recidivism (see Rossman \& Roman, 2003). Although the larger body of research on employment programs and recidivism is not encouraging (see Bushway \& Apel, 2012) the studies mentioned above illustrate that some programs - especially those that include comprehensive services - are promising.

Few studies have examined the role work-release halfway houses play in helping women secure employment after release from prison. To add to the research, this qualitative study aims to answer the following questions: How do women prepare for the job market, what are the challenges of securing work, and what factors facilitate the process? In-depth qualitative interviews with 33 women were conducted and analyzed to understand the job search process. It is important to understand some of the nuanced challenges and facilitators of the employment process for women returning from prison. While evaluation research tells us whether programs are effective, qualitative studies on the process are necessary for practitioners interested in implementing, or improving, correctional employment programs.

The following section provides an overview of the work-release halfway house program. Next, a detailed description of the methods used to carry out the study is discussed. The results are then presented to illustrate the job search process. Finally, the article ends with a discussion of the findings, study limitations, and program implications for improving the employment process for women.

\section{The program}

The Halfway House ${ }^{1}$ follows a gradual three-phase system that provides residents with privileges as they achieve certain goals and maintain good standing in the program. Once residents arrive at the Halfway House they are required to participate in a two-week program orientation and are unable to leave the facility unescorted. During the first $24 \mathrm{~h}$ of admission, residents are assigned a bed, ${ }^{2}$ provided with linens, and meet with staff for an in-depth program orientation that covers program expectations and regulations. During the first week residents are administered the level of service inventory-revised (LSI-R) and complete an employment and 
educational assessment. After this, they complete a job readiness training which includes an orientation to the job searching phase of the program, developing a resume, how to fill out applications, and interviewing strategies. During the second week of Phase I, residents meet with their case manager to develop a 30-day service plan that includes individualized treatment goals. Residents are required to sign and follow the treatment plan and are evaluated weekly by their case manager.

After residents complete the two-week orientation, they move into the second phase of the program where they are allowed to begin job searching and receive more visitation and community privileges. All residents are required to obtain fulltime employment or enroll in a full-time educational/vocational program. Residents are permitted to work part-time if they are enrolled in a part-time educational program. Residents with financial obligations (e.g. restitution or child care) are required to work at least part-time. Residents are allowed to search for jobs from Monday to Thursday between the hours of 8:00 am and 3:00 pm and must secure employment (or education/vocational program) within 30 days of beginning their job search. When on the job search, residents are required to make 'accountability calls' to the Halfway House once they arrive at a potential job site and before they leave. If they are at a job site for several hours, residents are required to call every two hours. In addition to making routine calls, residents are required to obtain the signature of the prospective employer to confirm their job searching activities.

The employment counselor works with residents to identify potential employers and even provides 'petty cash' for travel to residents with limited funds. After a resident receives a job offer, the employment counselor will visit the site and either grant or deny the resident permission to work at the selected employment site. Residents unable to obtain employment within 30 days are placed on an 'employment contract.' The employment contract further restricts their privileges in the community and inside the house. Residents on an employment contract must continue their job search. If employment is not secured within 10 days of being placed on the contract, residents face disciplinary action which could result in their return to prison. In addition to obtaining employment and/or enrolling in education programs, residents must meet weekly with employment counselor and case manager. These meetings are arranged to assist residents with the job search and their other individual needs. During the job searching phase, residents are eligible to receive one two hour visit per week. Visitation and other community privileges increase once residents begin to work.

Once residents secure employment they must maintain a 35 hour work week. Residents are not permitted to leave the work site at any time during their schedule, nor are they allowed to take days off without prior approval from Halfway House staff. The employment specialist maintains contact with all employers. To ensure residents are working a full-time schedule, they are required to submit their pay stubs to program staff. After residents receive their first paycheck, they are mandated to pay $30 \%$ of their wages toward house maintenance fees. Residents are also required to open a savings account, maintain a budget, and are only permitted to have 50 dollars in spending money per week.

\section{Methods}

The findings discussed in this paper were extracted from interview transcripts of women residing at the Work-Release Halfway House in New Jersey. The larger 
study from which these findings came was designed to capture women's perceptions and experiences with prison and halfway house programming, their support systems, childhood experiences, and release plans. This article, however, focuses on women's experiences of job searching and working while at the Halfway House. The study aimed to answer the following questions: How do women prepare for the job market, what are the challenges of securing work, and what factors facilitate the process?

\section{Data collection}

All women residing at a New Jersey Halfway House between June 2007 and November 2007 were eligible to participate in this study. All participants were previously incarcerated in New Jersey's Edna Mahan Correctional Facility (NJDOC). Forty-three women were residing in the Halfway House on the day of the first interview. Thirty-five women were conveniently selected (based on availability) to be interviewed and 33 agreed to participate. ${ }^{3}$ Before each interview the researcher informed participants about the voluntary nature of the interview and that, confidentiality and anonymity would be protected. After each woman agreed to participate the researcher asked for further permission to record the interview. Twenty-nine participants agreed to have the interview recorded. Each interview ranged from 30 minutes to two hours. Drawing on existing literature, the interview protocol was structured around a series of broad questions on women's pathway to prison, their experience during incarceration, the transition to the Halfway House, daily life at the house, searching for employment, addressing other re-entry needs (e.g. housing, family reunification, and treatment), and expectations for re-entry to the community. All recorded interviews were transcribed by the researcher afterwards. The researcher took detailed notes during the four interviews where participants refused to be recorded. Additionally, demographic and criminal history data was collected from participant case files. Data from case files included Pre-Sentence Investigation Reports, a Correctional Facility Assessment, and the LSI-R conducted by Halfway House staff.

\section{Analysis}

Analytical memos were written throughout the interviewing process to identify early themes. This step was useful in probing participants on emerging themes, and was also used to develop an initial code list. Since the interviews covered a wide range of topics, the researcher identified subsections of the transcripts where respondents specifically spoke about searching for employment, challenges with finding work, help securing a job, and types of employment secured. A process of initial coding then took place as a method of studying fragments of transcripts (Charmaz, 2006). As segments of transcripts were labeled using the initial code list, the researcher analyzed the meaning of the participants' words by writing additional analytical memos (Strauss \& Corbin, 1998). After this step, a second analytical phase of focused coding was applied. During this phase the qualitative software program, Atlas.ti, was used to aid in making connections between interviews and to search for additional themes related to women's job search experience. This phase allowed the researcher to further identify aspects of the data that may have been overlooked during initial coding and also allowed for greater comparison between 
participants (Charmaz, 2006). This comparison method was useful in further developing themes related to the employment search process. Lastly, to develop a sample profile, the researcher reviewed case files and analyzed the data using descriptive statistics related to demographic and criminal history. Case files were especially useful in reviewing the employment history of women in the sample. Comparing participants' employment history with their job search experience was a useful triangulation method that provided greater context for their experiences.

\section{Study sample}

The average age of interviewees was 39. Women were primarily African-American $(52 \%)$, followed by $27 \%$ White, and $21 \%$ Hispanic. The average length of time participants remained in the program was 202 days (with a range of 51-475 days). The length of time in the program varied and often depended on how much time remained on their sentence until parole eligible. More than half of the sample was unmarried $(61 \%)$, and the majority had at least one child under the age of 18 $(64 \%)$. Sixty percent of participants had a high school diploma or GED. Sixtyseven percent were frequently unemployed prior incarceration. Fifty-four percent have little to no work history, and $45 \%$ had extensive work experience. The majority of the sample had an extensive criminal history with $58 \%$ having three or more criminal convictions. Sixty-four percent of the sample had a history of substance use, however only $49 \%$ had a current substance abuse problem. An indication of a mental health problem was less frequently identified. Twenty-four percent of the sample reported receiving previous mental health treatment. In addition, 46\% experienced domestic violence and 30\% were sexually abused in their childhood.

\section{Results}

The majority of participants $(76 \%)$ were able to secure employment while residing at the Halfway House. Those not working were either enrolled in a full-time education, substance abuse, or mental health program. Three participants did not find work due to health issues. Participants found work in various fields including the medical, restaurant, fast food, and customer service. Most participants were able to secure employment within 30 days of beginning the job search, although a few took longer. The majority (64\%) landed work in low-skilled jobs. Employed participants, and those actively job searching, were asked various questions about the job searching process and establishing employment. Below are several themes that emerged from the interviews. Themes are categorized into two broad categories: job search barriers and sources of help.

\section{Job search barriers}

Participants shared many stories about the discouragement and anxiety of the job searching process. Participants expressed frustration and anxiety over explaining their halfway house status, not landing a job, the inability of finding a pay phone to make accountability calls, fear of returning late to the Halfway House due to public transportation delays, legal and program job restrictions, and for non-local participants the stress of being unfamiliar with the area. 


\section{Double stigma}

An additional stressor, frequently cited in the literature, was the stigma associated with having a criminal record (Sampson \& Laub, 1993; Solomon et al., 2001; Western et al., 2001). Experiencing stigma and employment rejection is a common experience for prisoners returning home. In this study, participants had to deal with a double stigma - having a criminal record and living in a halfway house.

During the job search, residents were required to disclose their halfway house status to potential employers. This policy was developed to hold residents accountable for all community movements, and to verify job search activity. When out on the job search, residents were required to obtain the signature of all potential employers. Many participants perceived this policy as off-putting and several stated they felt humiliated over disclosing their status. Similar to what other researchers found (Hattery \& Smith, 2010), some participants felt that the disclosure hurt their chances of obtaining employment. According to Debbie,

It was embarrassing. I lost a couple of jobs because of that, to tell you the truth, you know - they knew I was from a halfway house or a program and they didn't want to hire me.

Another participant, Susan, would not have disclosed her criminal status if she was living elsewhere.

The only fear I had was, I mean I am so use to job searching. The only fear was telling them where I was coming from. If I had been on my own I would have never said it or mentioned it.

Although the majority of participants felt stigmatized and embarrassed about disclosing their halfway house status, a few participants did not appear bothered by this disclosure. They saw it as part of the process of being in a halfway house. The researcher asked the following resident how employers react when presented with the job search verification form.

They have to stamp it [job search form] with the company name. Basically that will show that you have been there. Me - I take care of my business. Everything else I just sit back. It is not hard for me cause I am not ashamed of as far as my criminal behavior and drug addiction. I am not ashamed. They [employers] are very understanding. If you ask them to please sign this because I am in a halfway house. You have to present yourself that you are in a halfway house so that is what I did. You need that paper stamped stating that I was there. Or if they don't have a stamp they give me their business card so I come back with that. Nancy

Although the experience was stressful for many women going through the job search process, the rejection related to their criminal records was also perceived as beneficial. Women spoke about how the employment rejection prepared them for the reality of dealing with stigma after release from the program. They learned to manage the stress and disappointment, and how to respond to questions about their criminal history (see Cantora, 2013). 


\section{Program regulations}

Making accountability calls when out on the search was another challenge participants spoke about. Participants were fearful of missing these calls because they did not want to violate program rules and risk returning to prison. Participants described struggling to find working phones and running out of money to make calls.

You have to call every hour or every two hours when you're at a place, and that's kind of like confusing because if you had a job interview how are you going to get out the next couple of hours, you know what I'm saying? You know, when - it's kind of hard when you don't have money. They give you the money to pay the bus fare, they do give you that. Anna

The expense of making accountability calls and transportation also placed additional stress on residents. Several participants were able to save money from their prison job and others received assistance from their families. Residents with no financial support were provided with petty cash with the condition that they would reimburse the House once employed. To avoid paying for accountability calls, participants sometimes asked potential employers to use their telephone. Two participants described situations where they were denied access to the employer's telephone. They both attributed the refusal to their halfway house status.

Oh my God, I went to [names business]; I don't know if you heard of that place. That lady looked at me, she had her purse on the floor like this and I said I am from the House, may I use the phone please, I need to make my contact call and I came here for an interview. She looked at me and looked at her purse, grabbed and it put it on her lap and would not let me use the phone. So I am running around looking for a phone, because if you don't make that contact call you get in trouble. It's very hard thing to do, to find people like that, they not going to understand. All they know is that you're a criminal and you're in front of her, she not going to see I am a changed person. I felt like crying. She thought I was going to steal her purse and run. I felt humiliated. Jenny

The requirement to find work within 30 days of starting the job search added an additional layer of anxiety for many residents. This requirement pushed residents to search for work in places that would more likely result in quick employment. For example, most women sought out work in fast food restaurants. These women were able to obtain work within the 30-day mandate. Women who had higher qualifications (i.e. had a college education or certified in a specific field) were discouraged from working in the fast food industry. These participants often had extensive employment histories and were encouraged by staff to find a skilled job. Although these participants were anxious about not having a job within the 30-day requirement, staff informed them as long as they were making an effort to find work they would extend their search time. When participants wanted to give up and settle on a low-skilled job, staff encouraged them to continue searching.

After a month of unsuccessfully job hunting, Beth was ready to apply to McDonald's. Program staff encouraged her to take more time to search for employment that would fit her skill set. She eventually found a job she was satisfied with and one that also paid well. 
I wasn't just trying to get any kind of job. After like two months of not getting a job I was like look can I just go to McDonald's? And Ms. A was like 'No, you're too qualified to go to McDonald's.' I am like but I can't find anything else and McDonald's would hire me. This is a work release program you have to work. When I first got here they said I would give you 30 days to find a job and if you don't find a job you go back to Clinton [prison]. I was like oh my God, yeah it was 16 and I was still looking. The reason they didn't put me on an employment contract, because they see me trying every day. I was spending a fortune. I was going out every day. I was persistent; I was not giving up until I found a job. I was like someone is going to get me a job. Like one lady I went to dental care, she said 'you know you are overqualified for the job but I can't hire you because of your background.' So yeah a lot of jobs didn't give me ... but I was determined I was going to get a job and it was going to be the kind of job I wanted. I finally found something making \$13 an hour. And I get bonuses! Beth

Several residents discussed turning down a job because it interfered with the mandated in-house treatment group. During the time period this study was conducted, two mandatory treatment groups were offered inside the Halfway House. Based on individual needs women were enrolled in either the three-month substance abuse or gender-responsive program. Treatment groups occurred twice a week from $6 \mathrm{pm}$ to $8 \mathrm{pm}$ Gail, a college-educated resident, described being told by program staff that she could not apply to McDonald's because she had a college education and the qualifications to obtain a more skillful job. After being rejected numerous times, ${ }^{4}$ the employment counselor allowed Gail to apply to McDonald's and she was immediately hired.

It took me a while to find a job, I was told that I could not work in fast food so I went to [names retail store $]^{5}$ and I got the job but then they rejected me because of my [violent] charge. My second offer I had to reject because of the [treatment] groups I had to take at night. I tried [names retail store] - didn't get it. It annoyed me, but it's a reality and I am glad to be going through it here and not at home. I finally got a job at McDonald's, I don't love it, but I am happy to get a pay check and to have a routine. I work with my friend [another resident]. Gail

Other participants spoke about changing their work schedules around to attend groups. Even though most employers were understandable and allowed participants to change their work schedules, participants expressed frustration over leaving work early but were willing to do so because attending groups was a program requirement.

\section{Legal and program restrictions}

An additional barrier was the restrictions on working in certain professions. The New Jersey state laws prohibiting offenders from certain work were part of the challenge for some women (some examples include: establishments serving liquor; businesses that handle personal records; security work; places that work closely with children, the elderly, and the physically/mentally ill). Additional regulations developed by the Halfway House further restricted residents from certain jobs. For example, residents were prohibited from working certain hours (i.e. overnight) and from working in a location without a telephone. Residents were also unable to work in a business where another resident acts as a manager. 
Some residents wanted to find 'easy' jobs even though they were overqualified for the job. Aspiring to work at McDonald's was a common response because residents were aware of their non-discriminatory policy of hiring people with criminal records. As illustrated below, Pauline discussed plans to obtain employment at McDonald's not only because they hired individuals with criminal records, but also because she knew she could later transfer to a store closer to her home. At the time this interview was conducted, Pauline was getting ready to begin the job search and was worried staff would not allow her to pursue this job choice.

The reason I want to go there is (A) they hire ex-convicts and (B) they're all over, you know, so I can just transfer - if I go home transfer to one right up there and I'll have a job, you know. I won't have to go through searching for a job again. So I'm hoping that she allows me to do that. My understanding is that she - They don't want you to go into the fast-food service, like oh, God, you're a typical inmate. You know what I mean? Well, you know, I mean, it's - it's not a bad job. In the management end of it, it's not a bad job. Pauline

\section{Location}

Another difficult aspect of the job search was the unfamiliarity of the area for nonresidents. Many non-area participants expressed frustrations about not knowing the area and not having connections. According to Jamie,

I haven't found a job yet. I mean, I don't know nothing about this place, I don't know where to go or I don't know where to look. Even Ms. A, tells me she'll have something for me Monday, whatever. I mean, I need a job, I want a job, I want to work. I want to get out of this building.

Several also spoke about wanting to return to old employers but were unable to do so due to the far distance. These participants discussed returning to old employers, working with family, or finding and securing a specific job in their home community once released from the Halfway House.

The multiple barriers associated with finding work, coupled with the pressure to find employment within 30 days, left many participants discouraged with the job search experience. As participants waited for employers to call them, they expressed anxiety of never obtaining a job. For many participants, living at the Halfway House did not make the job search experience any less challenging; it did, however, provide residents with a realistic perspective of the challenges associated with finding work after release from prison. Regardless of the multiple barriers experienced during the job search, participants received help through various sources that eventually led to obtaining employment.

\section{Sources of help}

The second category related to the employment search phase is the various sources of help women received when trying to obtain work. Participants received help through various sources: Halfway House staff, the local One Stop, other residents, understanding employers, and social networks. 


\section{Program staff help}

Participants had mixed responses about the role the Halfway House plays in facilitating the job search. Several spoke about receiving some assistance from the employment counselor, which often included basic preparation on how to answer interview questions and a few discussed receiving job leads.

Yes, she gives us a lot of leads and she has given us instructions on how to go out there and be presentable and how to be on interviews. She does a lot for us and she deals with a lot of people. I am not saying she is under a lot of stress it's just that she has to deal with a lot of residents in here. But she always gives us job leads every day. She always got something for us. I don't mean one thing, it will be a couple things that we can put our pass in to go out. Nancy

Several residents went to other halfway houses either before entering the Halfway House, or when they were previously incarcerated. This experience shaped their expectations and perceptions of the program. They compared the employment assistance between halfway houses, and felt that the Halfway House should do more to help residents find work. Stacy felt that the employment counselor should find her a job, since that had been her experience in the past. Most participants recognized that the employment counselor was overburdened and felt that staff should provide more assistance with finding work, including hiring additional staff to help.

If you are supposed to be a work counselor than you are supposed to be getting us a job and you should be doing that. It shouldn't be about me getting on the phone to get the job. Like at [names other halfway house] Ms. D is the employment counselor and she has two assistants. When I got there and I went on work release she said 'look I got a contract already in the work and I am going to send you there.' I got off work release on Monday, Tuesday I went for interview. I came home and was working on Wednesday. She already was out in the community and set up jobs for us to go to. Where this employment counselor - they don't have that here. She is only one person. They don't have other people - employment staff - only one person can't do that. There are so many women in there. Stacy

When asking participants how the Halfway House can improve their programs and services, several recommended hiring additional staff to help with employment. Participants shared the perception that the employment counselor was overburdened with 'too many residents' and could not provide full support to all residents. In addition to hiring more staff, women recommended setting up a resource board with job openings, receiving information about specific places that hired formerly incarcerated people, and opportunities to leave the facility early in the morning to job search.

\section{One-stop career center help}

Halfway House staff also refers residents to the One Stop Career Center for additional employment assistance. The One Stop provides employment assistance to all individuals seeking employment, including services such as resume preparation, interview skills, job readiness, life skills, referrals to education and vocational programs, and job placement services. Participants discussed receiving some of these services, but none receive job placement. The most common services that participants received were job leads, applications, and employment-related workshops. 
The researcher asked Rachel how job searching was going. She described some benefits and drawbacks of the One Stop.

I went to One Stop yesterday from 11:30 to 4. What happened was I was on the computer. I was looking up stuff. I didn't find anything, then I went to the desk and asked for a counselor. She gave me a website called Career Builders. The thing with that is they have jobs for you but they don't have the addresses and the phone numbers and stuff like that, because that's what we need to give Ms. A so we can go out. And so I was just on the computer. Then we went to this boring orientation. The lady didn't know what she was talking about, whatever, so it just basically got me out of the building, just to say I went out. But I'm going to go back Monday because they give out applications for the [names business] place. And there was like seven of us from - from here at One Stop yesterday. Rachel

Another participant discussed receiving job leads from both the One Stop and the Halfway House employment counselor. Although one of the job leads resulted in employment, the job was not stable and she ended up unemployed. After this interview, Monique started the job search all over again and eventually found another job a few weeks before her release.

I went to One Stop. The women there, she is excellent, she is always given me leads to go. Ms. A I guess got a call from [names business], so she sent me and several other females out to [names business]. I just wish I went to another job, I would still be working right now. They laid us off, like last Monday and only called us back because people are on vacation. I mean truthfully speaking. I wish I would have went another route and got a stable job where I wouldn't have had that problem. But it is what it is. Monique

\section{Social networks}

Returning to the same neighborhood strengthened employment opportunities for local women. These women described finding jobs through social contacts, previous employers, and by just knowing where to search. Jenny described finding a job through an old acquaintance. Not only did she land a job, but she was also able to help other residents find employment through this contact.

Took me two weeks. I went to One Stop and there was this guy I knew and he gave me his card and said they were hiring there. See it's good to be from [area], again. So, I took the card and gave it to the Employment Specialist to let her check into it. So I kept calling the guy and calling him until he was sick of hearing my voice and he called me. I am not the only one that works there. Two other girls work with me. And then Ms. A just sent I think it was four or five other girls. Jenny

Another participant discussed being restricted to returning to her previous job due to the Halfway House policies. However, because she had worked in the local area for many years prior her incarceration, she was able to reach out to an old employer. Knowing employers and having an extensive record of employment allowed her to return to an employer who recognized her work ethic.

Actually, I knew I could go back to the job I had but due to the procedures here I wasn't allowed to go back to the jobs I had. Some you can't do with personal records and some you couldn't work because of the time frame. So, I knew [names restaurant] because I had worked there part time and I knew the manager and I asked him ... he 
knew the predicament I was going through. He said you worked so hard. I explained to him what happened. Like I said, I didn't think I was going to be incarcerated for so long. I thought I would just get a bracelet and go home. Ella

Anna, a participant familiar with the area, did not believe knowing the area would help her find a job. Anna had little job experience and was unemployed for most of her life. Even though she was unable to depend on social networks, she was able to receive assistance from both the Halfway House employment counselor and the local One Stop. The employment counselor helped her with her resume and contacted several places to inquire about hiring. The One Stop provided her with information on what employment establishments hire people with criminal records.

No, I don't feel like that because I know the area, but it's still hard for ex-offenders to get jobs, and you have to know exactly which place that does hire ex-offenders. And when we went to the meeting - we went to One Stop yesterday and we had to actually take the orientation thing yesterday, and they gave us a list of places that hire ex-offenders. So, you know, that kind of helped me a little bit, so I can look for the places that they gave me and call them and ask them if they're hiring, so that's a good thing. A lot of McDonald's stores hire ex-offenders. I got real good leads going for all next week. Anna

\section{Resourceful residents}

Most participants with limited employment histories were able to secure low-skilled jobs within the 30-day job search period. Several participants spoke about receiving job leads from other residents at the Halfway House. Employed residents shared information about job openings at their workplace. Learning about job opportunities from other residents appeared to help many participants land jobs. Participants often discussed working with friends they made at the Halfway House. Kate spoke about taking over the job of a resident who was about to be released.

I got lucky. Someone who was leaving - I took her job - and now they're like you're not leaving when you leave are you? It's a diner. I like it. I'm tired, but I like it. They were waiting for me and then off blackout [orientation phase], I got off Friday and I started Saturday. There are people still job searching and they been here a few months.

\section{Understanding employers}

Although many participants described experiences of employers turning them away because of their status, others described encountering employers who 'understood' their situation. Even participants with serious violent crimes were able to find employers who gave them a chance. The following participant discussed using the 'tools' she learned at a previous halfway house, and the current house, to help answer tough interview questions about her criminal past.

They never asked me. At the [restaurant] did. The guy Frank did. He definitely did. We sat down and had lunch over it. I did not want to talk about it. But he asked. I told him I was young and it was a mistake and I rectified my mistake. And that I'm asking to be given a chance. He said I am going to give you a chance. He said it is a small world it's like you're not by yourself. I don't know what he's talking about that. But I guess it happens to a lot of people and I am not the only one. That is how I took it. That was it. I did not get into details though. I went around and in and over and back. Carol 
After serving 11 years in prison, Carol had her first employment experience at a different halfway house program. When job searching at her prior halfway house, she discussed being afraid to leave the building alone and was accompanied by staff until she felt comfortable on her own. She worked for two months before violating parole and returning to prison. She stated that her job searching experience at this halfway house was less stressful because of her prior experience at the first halfway house. For Carol, finding a job was not the cause of her anxiety, rather it was the fear of going out into the community and interacting with other citizens 'Like you just have to break the fear, once you're out there, you're out there.'

As illustrated above, the Halfway House provides some assistance preparing residents for the work force. Frequent forms of help were preparing residents for interviews, providing job leads (i.e. places to inquire about employment), and referrals to the local One Stop. Even though participants received some assistance from staff, most were left to find work on their own and did so through the help of other residents or understanding employers. Residents from the local area were at a greater advantage to find work through social networks, old employers, and by just being familiar with the area. Regardless of the help residents received with employment, having a criminal record and living in a halfway house aggravated the challenges typically associated with finding work at the skill level of the applicant.

\section{Discussion}

The purpose of this study was to understand the job searching process for women residing at a work-release halfway house. Many of the nuanced challenges and facilitators of the employment process have been highlighted. Some of the challenges with the job searching process included the double stigmatization of having a criminal record and living in a Halfway House. As a result, participants became discouraged, experienced rejection, and felt 'humiliated' disclosing their status. Regardless of release location, dealing with the stigma of a criminal record has been well documented in the literature (Sampson \& Laub, 1993; Solomon et al., 2001; Western et al., 2001). The additional stigma of halfway house status further contributed to the stress and anxiety of searching for work. Due to these stigmas, participants, even those with extensive employment histories, struggled to find jobs within their fields and often settled with fast food restaurant jobs because these jobs were the 'easiest' to secure. Participants also complained about the employment counselor not having enough time or resources to help residents find jobs. Although there were multiple barriers experienced during the search process, $76 \%$ of participants secured employment through various sources.

The Halfway House provided some assistance preparing residents for the work force. Frequent forms of help were preparing residents for interviews, providing job leads (i.e. places to inquire about employment), and referrals to the local One Stop. Even though participants received some assistance from staff, most were left to find work on their own. Residents from the local area were at a greater advantage to find work through social networks, old employers, and by just being familiar with the area. Regardless of the help residents received with employment, having a criminal record and living in a halfway house aggravated the challenges typically associated with finding work at the skill level of the applicant. Consistent with the 
literature (see Nelson et al., 1999; Solomon et al., 2001; Visher et al., 2011), the importance of social networks was a common theme throughout the interviews. There was also a qualitative distinction between participants from the local area vs. those from other areas of New Jersey. Local residents were at an employment advantage due to their familiarity with the area and their access to acquaintances and old employers, whereas participants from other parts of the state were unfamiliar with the community and did not have access to local social networks. Unlike local residents, non-residents sought temporary employment and had to quit their job once released. Many discussed plans to return to old employers or had ideas about where they would seek employment once back in their former community.

For those with an extensive employment background, the jobs secured were obtained just to fulfill the requirements of remaining in the program. These women had bigger plans than just working low-skilled jobs. This was evident in their persistence to enroll in educational and vocational courses to advance their job prospects. Most women, regardless of employment background, had no plans to maintain the same job when released. For many, their release location was too far from the Halfway House job making it impossible to maintain their position. Several women, working in the fast food industry, did speak about transferring to another store in their home community.

Three women with health-related problems were unable to work. Consistent with the literature (Richie, 2001; Visher et al., 2011) health conditions impact maintaining a job. Although a very small percentage of the sample in this study were unable to work, it is important to recognize that women with serious health conditions need a different host of services than what is typically provided in work-release programs. It should also be mentioned that women in this study were provided with temporary housing and did not have any household or family obligations. A valid assessment of their employment experience is lacking because of their current housing situation. As indicated in the literature, women experience a range of additional barriers related to family care and re-establishing relationships (Berman, 2005; Flowers, 2010; O’Brien, 2001; Richie, 2001). Future research on women's employment process should address these issues.

\section{Study limitations}

It is important to note the limitations of this study. Due to the small sample size and nature of data collection this method does not allow for generalizing findings to other female community correction programs within the state or other states. While some of the findings from this study are comparable to other research on the topic, women residing in other similar programs may have different experiences. A further limitation is the lack of follow-up. The researcher was unable to conduct follow-up interviews to determine whether participants maintained jobs once released, found new ones, struggled to find work in the same way they did at the Halfway House, and whether new barriers arose. Was the experience easier because of the head start received at the Halfway House? Future research should compare the job search experience process while residing in a community correction setting to the experience living in a non-restrictive setting.

Due to time constraints, another limitation was the lack of member checking. Member checking is an important strategy often conducted in qualitative studies to 
avoid researcher bias and data misinterpretation. The stress of living at a halfway house and feeling pressure to secure employment within a brief time period may have impacted women's perceptions of the program and their responses to the interview. It should be noted that several participants made comments about how the interview was actually helpful for them. For example, one resident was forced to end the interview early because of a scheduled meeting with the employment specialist. She asked if she could continue the interview later in the day and stated that the interview was helping her think about her plans for the future. There were many other anecdotes that led me to believe that the women were genuinely forthcoming and truthful. The fact that I was of the same gender as participants and had previously worked as a re-entry service provider with a similar population may have helped develop quick rapport. Perhaps, my presence over a six-month period made participants feel comfortable talking about their experiences. Of course, there were exceptions - the few women who provided very short responses and finished the interview in less than an hour.

\section{Program and policy recommendations}

Several program and policy recommendations should be considered for future research and program development. First, it should be noted that residing in a community corrections facility enhances the surveillance over the job search process and forces residents to secure low-skilled jobs. As evident by the findings from this study, the requirement to find work within 30 days restricted residents' ability to find jobs that met their employment/education skills. Securing work that is compatible with skills should be a priority of work-release programs. Even if securing immediate work is a mandate of the program, residents - especially those who plan to live in the surrounding community - should be encouraged (if not required) to continue their job search until they find compatible employment. As highlighted in the literature, higher quality jobs increases social control and decreases recidivism (Uggen, 1999), especially when jobs focus on skill-building (Latessa, 2012). According to Latessa (2012), low-quality jobs that don't enhance skill development may not lead to behavioral change. To be successful, Latessa argues that employment programs must also target attitudes and values about work. Securing work just to satisfy a program requirement may not lead to positive attitudes toward that job, and will likely result in low-skilled work. Focusing on skill-building and attitudes towards employment are two components that will potentially lead to sustainable and meaningful work.

Since many women secure temporary jobs due to the 30-day work requirement and the distance between the Halfway House and their intended release location, a second program recommendation is warranted. Developing a state-wide transitional job program may be beneficial to individuals released to halfway houses. Considered a promising employment model (Redcross et al., 2009), individuals are placed into temporary jobs, offered a range of support services, and provided with assistance finding permanent work. Since most women at the Halfway House engage in significant efforts to secure temporary work it may be useful to develop a program that places them into a transitional job while simultaneously working with them to find permanent jobs in the community they plan to return. This continuity-of-care approach would ensure that there is no employment gap between the time released from the Halfway House and the time they return to their home community. 


\section{Notes}

1. To protect the identity of staff and participants, the halfway house program is referred to as the 'Halfway House,' and participant and staff names have been changed to a pseudonym.

2. Room sizes at the Halfway House vary. Some rooms are very small and accommodate two to four residents, where some others are large and accommodate up to 11 residents. Residents share common bathrooms.

3. Eight women were not included in the study because they were released from the Halfway House before the researcher had a chance to approach them for an interview. The characteristics of these eight women are unknown.

4. This resident was incarcerated for a manslaughter charge and attributes this charge to not finding a skillful job.

5. The names of certain businesses are excluded to protect the identity of the participants. McDonald's is the only business named in this manuscript because many participants in this study applied and/or obtained work at this restaurant.

\section{Notes on contributor}

Andrea Cantora is an assistant professor in the School of Criminal Justice at the University of Baltimore. She received her doctorate in Criminal Justice from The City University of New York City/John Jay College of Criminal Justice. Her research interests include correctional rehabilitation and policy, community corrections, women and juvenile offenders, and prisoner re-entry.

\section{References}

Berman, J. (2005). Women offender transition and reentry: Gender responsive approaches to transitioning women offenders from prison to the community. Washington, DC: US Department of Justice, National Institution of Corrections.

Bureau of Labor Statistics. (2003). Earnings by educational attainment and sex, 1979 and 2002. Washington, DC: US Department of Justice, The Bureau of Labor Statistics.

Bushway, S. D., \& Apel, R. (2012). A signaling perspective on employment-based reentry programming: Training completion as a desistance signal. Criminology \& Public Policy, $11,21-50$.

Cantora, A. (2013). Building grounds for release: Women's perceptions of a community corrections program. Journal of Qualitative Criminal Justice and Criminology, 1, 197-220.

Carson, A., \& Golinelli, D. (2013). Prisoners in 2012. Trends in admissions and releases, 1991-2012. Washington, DC: US Department of Justice, The Bureau of Justice Statistics.

Chappell, C. A. (2004). Post-secondary correctional education and recidivism: A meta-analysis of research conducted 1990-1999. Journal of Correctional Education, 55, 148-169.

Charmaz, K. (2006). Constructing grounded theory: A practical guide through qualitative analysis. Thousand Oaks, CA: Sage.

Donnelly, P. G., \& Forschner, B. E. (1987). Predictors of success in a co-correctional halfway house: A discriminant analysis. Journal of Crime and Justice, 10, 1-22.

Flower, S. M. (2010). Employment and female offenders: An update of the empirical research. Gender responsive strategies for women offenders. Washington, DC: US Department of Justice, National Institution of Corrections.

Greenberg, E., Dunleavy, E., \& Kutner, M. (2007). Literacy behind bars: Results from the 2003 national assessment of adult literacy prison survey. Washington, DC: US Department of Education, National Center for Education Statistics.

Hattery, A., \& Smith, E. (2010). Prisoner reentry and social capital: The long road to reintegration. Latham, MD: Lexington Books.

Holzer, H. J., Raphael, S., \& Stoll, M. (2004). Will employers hire ex-offenders? Employer preferences, background checks, and their determinants. In M. Patillo, D. F. Weiman, \& B. Western (Eds.), Imprisoning America: The social effects of mass incarceration (pp. 205-246). New York, NY: Russell Sage Foundation. 
La Vigne, N. G., Brooks, L. E., \& Shollenberger, T. L. (2009). Women on the outside: Understanding the experiences of female prisoners returning to Houston Texas. Washington, DC: The Urban Institute.

Lalonde, R. J., \& Cho, R. M. (2008). The impact of incarceration in state prison and the employment prospects of women. Journal of Quantitative Criminology, 24, 243-265.

Latessa, E. J. (2004). Homelessness and reincarceration. Editorial introduction. Criminology \& Public Policy, 3, 137-138.

Latessa, E. (2012). Why work is important, and how to improve the effectiveness of correctional reentry programs that target employment. Criminology \& Public Policy, 11, 8791.

Latessa, E. J., \& Allen, H. E. (1982). Halfway houses and parole: A national assessment. Journal of Criminal Justice, 10, 153-163.

Latessa, E. J., \& Travis, L. F. (1991). Halfway house or probation: A comparison of alternative dispositions. Journal of Crime \& Justice, 14, 53-75.

LeBel, T. P. (2012). 'If one doesn't get you another one will': Formerly incarcerated persons' perceptions of discrimination. The Prison Journal, 92, 63-87.

Legal Action Center. (2004). After prison: Roadblocks to reentry. A report on state legal barriers facing people with criminal records. New York, NY: Author.

Lynch, J., \& Sabol, W. (2001). Prisoner reentry in perspective. Washington, DC: The Urban Institute, Justice Policy Center.

Mackey, R., \& Fretz, R. (2007). Female offender outcome research study (Community Education Centers). Philadelphia, PA: Drexel University.

Mallik-Kane, K., \& Visher, C. (2008). Health and prisoner reentry: How physical, mental, and substance abuse conditions shape the process of reintegration. Washington, DC: The Urban Institute.

Nelson, M., Perry, D., \& Allen, C. (1999). The first month out: Post-incarceration experiences in New York City. New York, NY: The Vera Institute of Justice.

O'Brien, P. (2001). Making it in the free world: Women in transition from prison. Albany: State University of New York Press.

O'Brien, P. (2002). Reducing barriers to employment for women ex-offenders: Mapping the road to reintegration. Chicago, IL: Safer Foundation.

Pager, D. (2002). The mark of a criminal record. American Journal of Sociology, 108, 937975.

Petersillia, J. (2001). When prisoners return to the community: Political, economic and social consequences. Corrections Management Quarterly, 5, 1-10.

Redcross, C., Bloom, D., Azurdia, G., Zweig, J., \& Pindus, N. (2009). Transitional jobs for ex-prisoners: Implementation, two-year impacts, and costs of the Center for Employment Opportunities (CEO) prisoner reentry program (A report from MDRC-Building Knowledge to Improve Social Policy). New York, NY: MDRC.

Richie, B. E. (2001). Challenges incarcerated women face as they return to their communities. Crime and Delinquency, 47, 231-245.

Rossman, S. B., \& Roman, C. G. (2003). Case managed reentry and employment: Lessons from the opportunity to succeed program. Justice Research and Policy, 5, 75-100.

Sampson, R. J., \& Laub, J. H. (1993). Crime in the making: Pathways and turning points through life. Cambridge, MA: Harvard University Press.

Scroggins, J. R., \& Malley, S. (2010). Reentry and the (unmet) needs of women. Journal of Offender Rehabilitation, 49, 146-163.

Solomon, A., Roman, C. G., \& Waul, M. (2001). Summary of focus group with ex-prisoners in the district: Ingredients for successful reintegration. Washington, DC: The Urban Institute.

Strauss, A., \& Corbin, J. (1998). Basics of qualitative research: Techniques and procedures for developing grounded theory. Thousand Oaks, CA: Sage.

Travis, J. (2005). But they all come back: Facing the challenges of prisoner reentry. Washington, DC: Urban Institute Press.

Uggen, C. (1999). Ex-offenders and the conformist alternative: A job quality model of work and crime. Social Problems, 46, 127-151.

Visher, C. A., Debus-Sherrill, S. A., \& Yahner, J. (2008). Employment after prison: A longitudinal study. Washington, DC: The Urban Institute. 
Visher, C. A., Debus-Sherrill, S. A., \& Yahner, J. (2011). Employment after prison: A longitudinal study of former prisoners. Justice Quarterly, 28, 698-718.

Visher, C., \& Travis, J. (2003). Transitions from prison to community: Understanding individual pathways. Annual Review of Sociology, 29, 89-113.

Western, B. (2007). The penal system and the labor market. In S. Bushway, M. A. Stoll, \& D. F. Weinman (Eds.), Barriers to reentry? The labor market for released prisoners in postindustrial America (pp. 335-360). New York, NY: Russell Sage Foundation.

Western, B., Kling, J. R., \& Weiman, D. (2001). The labor market consequences of incarceration. Crime and Delinquency, 47, 410-427. 
Copyright of Criminal Justice Studies is the property of Routledge and its content may not be copied or emailed to multiple sites or posted to a listserv without the copyright holder's express written permission. However, users may print, download, or email articles for individual use. 